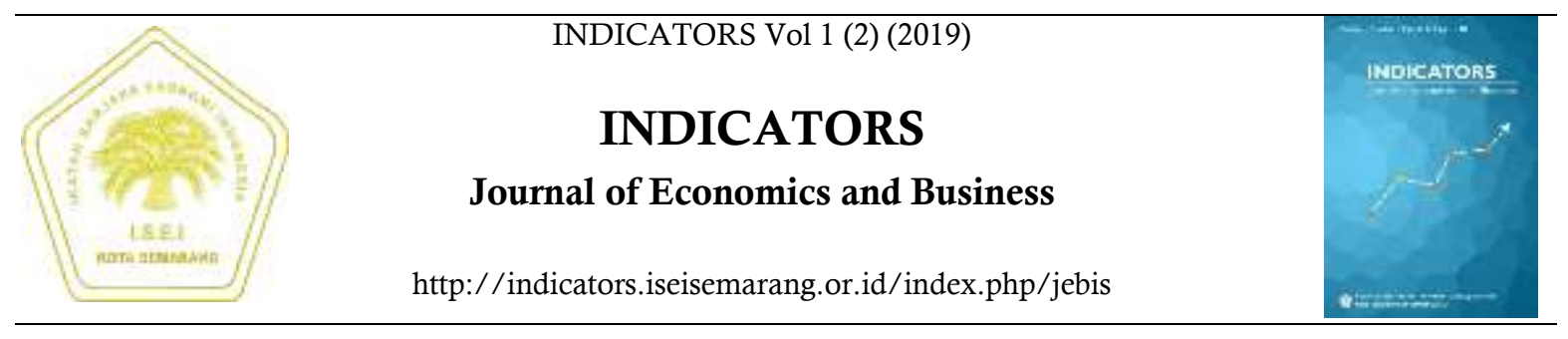

\title{
ANALISIS HUBUNGAN PARIWISATA DAN PERTUMBUHAN EKONOMI TERHADAP EMISI CO2 DI INDONESIA
}

\author{
Mela Dipa Sekar Putri ${ }^{\bowtie}$, Rida Oktayanti, Suci Amalia, Hilda Amalia
}

Fakultas Ekonomi, Universitas Negeri Semarang

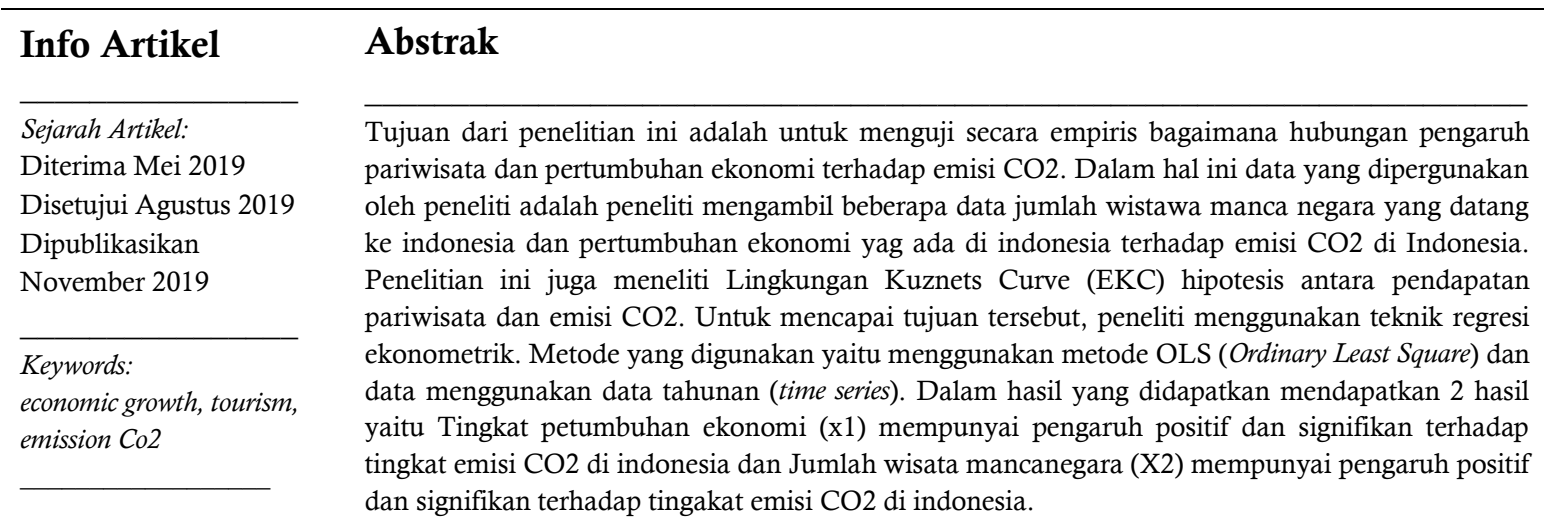

\section{Abstract}

The purpose of this study is to empirically examine how the relationship of tourism's influence and economic growth on $\mathrm{CO} 2$ emissions. In this case the data used by researchers is the researchers took some data on the number of foreign tourists coming to Indonesia and the economic growth that exists in Indonesia to $\mathrm{CO} 2$ emissions in Indonesia. This study also examines the Environmental Kuznets Curve (EKC) hypothesis between tourism income and $\mathrm{CO} 2$ emissions. To achieve this goal, researchers used econometric regression techniques. The method used is using the OLS (Ordinary Least Square) method and data using annual data (time series). In the results obtained get 2 results namely the level of economic growth ( $x 1$ ) has a positive and significant effect on the level of $\mathrm{CO} 2$ emissions in Indonesia and the number of foreign tourism (X2) has a positive and significant effect on the level of $\mathrm{CO} 2$ emissions in Indonesia.

\footnotetext{
${ }^{\square}$ Alamat korespondensi:

Fakultas Ekonomi Universitas Negeri Semarang Gedung L1,

Lantai 1, Kampus Sekaran Gunungpati Semarang

E-mail: (meladipa06@gmail.com)
} 


\section{PENDAHULUAN}

Pariwisata dan pertumbuahan ekonomi adalah suatu hal yang berkaitan, bahwa dengan adanya tempat wisata maka akan mengundang bertambahnya pertumbuhan ekonomi di suatu wilayah tersebut. Indonesia merupakan negara yang memiliki kekayaan alam yang melimpah, baik sumber daya alam yang dapat diperbaharui dan yang tidak dapat diperbaharui ataupun sumber daya yang dapat dinikmati masyarakat yaitu dengan menikmati keindahanya. Wilayah Indonesia yang sangat luas yaitu 7,81 juta $\mathrm{km}^{2}$ dan terdiri dari wilayah laut $3,25 \mathrm{~km}^{2}$, daratan 2,01 juta $\mathrm{km}^{2}$, dan zona ekonomi eksklusif yaitu 2,55 juta $\mathrm{km}^{2}$. Hal ini lah yang akan menjadi daya tarik tersendiri untuk Indonesia. Pariwisata merupakan kegiatan ekonomi yang bernilai utama dan penting bagi banyak negara dan dapat diterima secara luas di berbagai belahan dunia. Khususnya pada negara berkembang yang memanfaatkan pariwisata untuk menutupi kebutuhan mata uang asing di negaranya. Pariwisata memiliki kontribusi terhadap valuta asing, seperti : sektor bisnis, melalui peningkatan produksi industri dan pertanian, sehingga dapat memenuhi gelombang wisata yang semaki meningkat, serta mobilisasi perdagangan internasional dan domestik dan kegiatan berbagai industri terkait layanan yang meliputi transportasi, telekomunikasi, perbankan, agen perjalanan, dll (Çağatay 2015). Hal ini lah yang menjadi pertimbangan negara-negara berkembang mengembangkan potensi pariwisatannya, termasuk indonesia yang masih dalam kategori negara berkembang.

Dilihat dari tahun ketahun jumlah pariwisata yang ada diindonesia semakin banyak dari pariwisata buatan maupun pariwisata alam. Hal tersebut mendorong makin banyaknya mengudang turis mancanegara yang datang ke Indonesia untuk berkunjung ke wisata-wisata di Indonesia. Pada tahun 1974 turis manca negara yang datatang di indonesia sebanyak 313.452 dan ditahun 2015 mencapai 10.230.775 wisatawan mancanegara. Dari data tersebut menandakan banyaknya pertambahan yang cukup pesat para wisatawan di Indonesia yang datang dari tahun ke tahun. Semakin banyaknya para wisatawan dari berbagai negara membuat keuntungan bagi Indonesia sendiri. Dengan semakin banyaknya warga asing yang berkunjung ke Indonesia dapat mendorong pertumbuhan ekonomi di Indonesia.

Para wisatawan dari manca negara yang datang di Indonesia secara langsung akan menambah devisa negara. Devisa Indonesia pada tahun 2015 sebesar 12.225,89 US\$ meningkat dibandingkan di tahun 2014 yaitu sebesar 11.166,13 US\$, hal tersebut menandakan bahwa pertambahan jumlah wisata di Indonesia setiap tahunnya juga akan membuat pertambahan devisa negara Indonesia. Selain itu juga para wisman tersebut akan melakukan kegiatan ekonomi selama berkunjung di Indonesia.

Jika kita lihat secara langsung banyaknya wisata manca negara yang datang ke Indonesia memberikan banyak keuntungan bagi negara Indonesia sendiri. Namun sejalan dengan hal tersebut, suatu kegiatan juga akan memberikan efek eksternalitas tidak hanya eksternalitas positif tetapi juga eksternalitas negatif. Jika efek pariwisata memberikan efek positif terhadap pertumbuhn ekonomi suatu negara tetapi juga pariwisata memberikan efek negatif terhadap lingkungan di Indonesia sendiri. Dengan banyaknya wisatawan yang datang untuk berkeliling di wilayah Indonesia otomatis akan membutuhkan kendaraan sebagai transportasi untuh berpindah dari tempat satu ketempat lain. dari kendaraan umum hingga pribadi yang dibutuhkan para wisatawan. Kendaran tersebut setiap beroperasi menimbulkan asap yang dikeluarkan yaitu emisi CO2. Hal tersebut mengakibatkan semakin tercemarnya udara di Indonesia karena polusi emisi CO2. Semakin meningkatnya emisi $\mathrm{CO} 2$ yang ada di Indonesia menandakan semakin buruknya kondisi lingkungan terutama pada udara di Indonesia. Dimana Sarana lingkungan pemukiman merupakan fasilitas penunjang yang berfungsi untuk penyelenggaraan dan pengembangan kehidupan ekonomi, sosial dan budaya. Contoh sarana lingkungan pemukiman adalah fasilitas pusat perbelanjaan, pelayanan umum, pendidikan dan kesehatan, tempat peribadatan, rekreasi dan olahraga, pertamanan, pemakaman. 
Dilihat dari data bahwa emisi di Indonesia semakin lama semakin meningkat, walaupun terkadang terjadi penurunan dari tahun ini dibandingkan tahun lalu tetapi penurunan tersebut kecil, sedangkan dilihat dari beberapa tahun rata-rata emisi $\mathrm{CO} 2$ di Indonesia mengalami peningkatan. Pada tahun 1974 emisi $\mathrm{CO} 2$ di Indonesia sebesar 0,40229245 dan sedangkan di tahun 2014 emisi CO2 di Indonesia meninkat sebesar 1,81937838. Angka itu menunjukan peningkatan yang cukup besar emisi $\mathrm{CO} 2$ di indosia. Semakin besar emisi $\mathrm{CO} 2$ yang ada di Indonesia menandakan semakin buruknya kualitas udara di Indonesia.

Dalam hal ini juga kita bisa melihat bahwa semakin tinggi pertumbuhan ekonomi di indonesia juga mengakibat semakin tingginya emisi CO2. Hal ini diakibatkan karena pertumbuhan ekonomi di indonesia terjadi akibat kenaiakan pendapatan perkapita penduduk di indonesia. Karekteristik masyarakat indonesia diamana mereka yang memiliki pendapatan tinggi akan memiliki lebih banyak jumlah kendaran di indonesia. Maka dari asap kendraan lah yang merupakan salah penyebab menyumbang polusi emisi $\mathrm{CO} 2$, selain itu pertumbuhan ekonomi di indonesia sendiri juga dipicu dengan perekonomian diindonesia yang semakin baik. Pertumbuhan perekonomian di indonesia ini di dorong dengan banyaknya industi yang berdiri di indonesia.Dimana Pendirian idustri tersebut akan menyebabkan semakin bertambahnya emisi $\mathrm{CO} 2$ di wilayah indonesia. Emisi $\mathrm{CO} 2$ ini di picu dari polusi udara yang di keluarkan dari efek eksternalitas produksi negatif dari industri yang didirikan di berbagai wilayah.

\section{TINJAUAN PUSTAKA}

Dampak dari pengembangan suatu pariwisata sering terjadi di tempat yang bersangkutan baik dari segi ekonomi, sosial, maupun lingkungan. Dalam upaya mempertahankan suatu pengembangan pariwista, salah satu hal penting yang perlu diperhatikan yaitu melihat dampak eksternalitas dari perkembangan wisata tersebut. Perkembangan pariwisata disuatau negara dapat memberikan keuntungan yaitu berdampak positif terhadap pertumbuhan ekonomi. Misalkan saja dengan adanya pariwisata dapat membuka peluang lapangan pekerjaan baru. Tetapi tak bisa dipungkiri juga bahwa perkembangan pariwisata memberikan dampak negatif terhadap lingkungan. Pada bagian ini, peneliti meninjau literatur menggunakan teknik time-series model ekonometrik oleh dua subbagian:

i) Pariwisata terhadap $\mathrm{CO}_{2}$

ii) Pertumbuhan ekonomi terhadap emisi $\mathrm{CO}_{2}$.

Menurut Sadono Sukirno (2010), pertumbuhan ekonomi merupakan perkembangan kegiatan dalam perekonomian yang mengakibatkan barang dan jasa yang diproduksi dalam masyarakat bertambah dan kemakmuran masyarakat meningkat. Permasalahan ekonomi ini me rupakan masalah makro dalam suatu negara dalam jangka panjang. Perkembangan kemampuan memproduksi barang dan jasa sebagai akibat pertambahan faktor-faktor produksi pada umumnya tidak selalu diikuti oleh pertambahan produksi barang dan jasa yang sama besarnya. Tulus T.H. Tambunan (2003) menyatakan bahwa pertumbuhan ekonomi merupakan kenaikan pada pendapatan nasional rill naik di suatu negara. Jadi perekonomian yang tumbuh atau berkembang jika terjadi pertumbuhan pengluaran riil. Suatu perekonomian dapat dikatakan mengalami pertumbuhan ekonomi jika jumlah barang dan jasa meningkat. Jumlah barang dan jasa dalam perekonomian suatu negara dapat diartikan sebagai nilai dari produk domestik bruto (GNP). Nilai GNP ini digunakan dalam mengukur persentase pertumbuhan ekonomi suatu negara.

\section{Pariwisata dan Pertumbuhan Ekonomi}

Teori ekonomi pariwisata berpendapat bahwa pertumbuhan ekonomi yang dipimpin pariwisata dapat terjadi ketika pariwisata memiliki dampak yang merangsang pada perekonomian melalui limpahan dan eksternalitas lainnya (Marin, 1992; Balaguer\&Cantavella-Jorda, 2002). Terdapat sejumlah studi yang secara empiris menyelidiki hubungan sebab akibat antara pariwisata dengan 
pertumbuhan ekonomi. Berdasarkan bukti empiris, empat untai literature yang berbeda mengenai hubungan kasual antara pariwisata dan pertumbuhan ekonomi dapat ditemukan, sebagai berikut:

a. Pertumbuhan ekonomi yang dipimpin pariwisata,

b. Pertumbuhan pariwisata berbasis ekonomi,

c. Hubungan umpan balik antara pariwisata dan pertumbuhan ekonomi, dan

d. Tidak ada hubungan sebab akibat

Salah satu studi empiris yang mengeksplorasi hubungan antara pariwisata dengan pertumbuhan ekonomi diantaranya Hazari dan Sgro (1995), mengembangkan sebuah model pertumbuhan dengan memasukkan pariwisata sebagai komponen tambahan untuk permintaan agregat domestik. Hasilnya, pariwisata mempunyai dampak positif terhadap pertumbuhan ekonomi jangka panjang. Studi lain yang menunjukan hubungan positif antara pariwisata dengan pertumbuhan ekonomi antara lain Studi Eugenio-Martı'n, Morales \& Scarpa (2004), dengan kasus Amerika Latin dalam periode 1985-1998, menunjukkan bahwa sektor pariwisata memberikan cukup pengaruh terhadap pertumbuhan.

\section{Pariwisata dan Emisi $\mathrm{CO}_{2}$}

Kegiatan pariwisata memang meninbulkan dampak negatif terhadap lingkungan dan dampak negatif tersebut tidak mampu di hindari. Kegiatan pariwisaa sendiri dalam pengoperasionalkannya melibatkan konsumsi energi dari bahan bakar fosil, hal tersebut yang dapat merusak lingkungn.apalagi dalam penggunaan transportasi , disini transportasi diguakan para turisman utuk berkeliling dari satu tempat ke tempat lain. Pengunaan transportasi inilah yang menghasilkan emisi CO2. Kegiatan pariwisata dalam ini jumlah wistawan yang datang ke suatu negara dapat mempengaruhi kondisi lingkungan di negara tersebut dalam hal ini yaitu Emisi CO2 (Sudharsha 2017). Meskipun pariwisata sendiri menjadi salah satu kontributor dalam upaya mempengaruhi perubahan iklim dan pemanasan global seperti yang diklaim oleh Scottet al. (2010), hubungan antara kegiatan pariwisata dan emisi $\mathrm{CO} 2$ relatif kurang dieksplorasi dalam literatur sampai dekade terakhir. Namun, penelitian sebelumnya pada umumnya mendukung efek negatif dari pertumbuhan pariwisata terhadap emisi CO2. Becken dan Simmons (2002) pariwisata sebagai pengguna besar terhadap konsumsi energi dan penyumbang dalm perubahan iklim global selain itu pernyataan bahwa kegiatan wisata (penerbangan misalnya pemandangan, jet boating atau perjalanan udara) menggunakan lebih banyak energi daripada tempat-tempat wisata (misalnya museum atau pusat-pusat pengalaman) lakukan di Selandia Baru pada tahun 2000. Kemungkinan, Gossling (2002) menunjukkan bahwa transportasi udara memiliki dampak terbesar pada konsumsi energi dibandingkan yang lain dan dapat menimbulkan dampak yang membentuk Emisi CO2.

Kegiatan pariwisata, khususnya pada transportasi dan akomodasi, dalam pengoperasiannya menggunakan konsumsi energi, terutama dari bahan bakar fosil. Penggunaan energi dalam kegiatan yang berhubungan dengan pariwisata mengarah ke jumlah emisi $\mathrm{CO} 2$ yang signifikan, dan industri dianggap sebagai salah satu kontributor penting terhadap pemanasan global dan perubahan iklim (Sudharshan 2018). Dalam kegiatan pariwisata atau kedatangan turis mempengaruhi konsumsi $\mathrm{CO} 2$ dan energi. Pariwisata yang dianggap sebagai industri tanpa asap sebagai faktor pembangunan ekonomi, mempengaruhi perkembangan keuangan dan tingkat emisi karbon dalam jangka pendek dan menyebabkan polusi udara bagi negara-negara di semua periode (Çağatay 2015).

\section{Pertumbuhan Ekonomi dan Emisi CO2}

Pertumbuhan ekonomi dan emisi $\mathrm{CO}_{2}$ dijelaskan dalam sebuah hipotesis Environmental Kuznets Curve (EKC). Hipotesis EKC memperlihatkan kontribusi pertumbuhan ekonomi terhadap emisi yang lebih tinggi tetapi pertumbuhan ekonomi lebih lanjut dapat menurunkan degradasi lingkungan. Hal ini dikarenakan kemajuan teknologi dan pergeseran ke ekonomi berbasis jasa (Galeotti, 2007). Hipotesis Kuznet mengidentifikasi pertumbuhan 
ekonomi sebagai faktor yang menentukan perubahan tingkat kualitas lingkungan. Didalam negara tingkat Emisi $\mathrm{CO} 2$ akan meningkat seiring dengan peningkatan pendapatan negara ataupun pertumbuhan ekonomi, akan tetapi kualitas lingkungan dalam seiring berjalannya waktu juga akan meningkat seiring diikuti dengan peningkatan pertumbuhan ekonmi. Hal ini dapat dijelaskan oleh kurva kuznet U terbalik atau kurva $\mathrm{n}$ dimana pada periode tertentu peningkatan pertumbuhan ekonomi diikuti dengan peningkatan Emisi CO2 ada penurunan kulitas lingkungamn hal ini biasanya terjadi di negara-negara berkembang dan misikin karena penggunaan teknoli yang kurang ramah lingkungan. Tetapi seiring periode waktu pertumbuhanan ekonomi akan diikuti dengan penurunan Emisi CO2 karena masyarakat sudah sadar akan pentingnya lingkungan bersih dan sehat dan menggunakan teknologi-teknologi yang ramah lngkungan hal ini terjadi di negaranegara maju (Kuznets, 1955). Periode tersebutlah yang disebut sebagai titik balik (turning point) dimana pertumbuhan ekonomi akan menurunkan degradasi lingkungan (Shaharir \& Alinor, 2013).

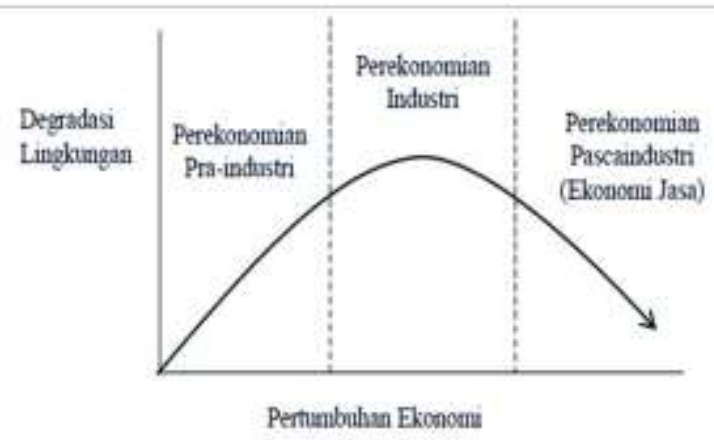

Sumber: Shaharir \& Alinor, 2013

\section{Gambar 1. Proses Titik Balik Hipotesis EKC}

Berdasarkan Gambar 1 yang menjelaskan tahapan yang terjadi dalam hubungan pertumbuhan ekonomi dan kualitas lingkungan, terlihat bahwa tahapan EKC terbagi menjadi tiga. Penjelasan pertama dari hubungan kurva Uterbalik Kuznet adalah tahapan pertumbuhan ekonomi melalui transisi dari pertanian ke industri, kemudian pasca-industri dengan system perekonomian berbasis jasa. Kerusakan lingkungan cenderung naik karena perubahan struktur ekonomi dari pedesaan ke perkotaan, dan dari pertanian ke industri sebagai produksi masal, dan pertumbuhan konsumsi. Hal ini kemudian menurun dengan perubahan struktur ekonomi yang kedua dari industri berat berbasis energi menjadi industri dan jasa berbasis teknologi (Panayotou, 1993). Pada tahap pertama dari industrialisasi, polusi bertambah dengan cepat karena orang lebih tertarik dalam pekerjaan dan pendapatan daripada udara dan air bersih. Berkaitan dengan itu, masyarakat terlalu miskin untuk membayar pengendalian dan regulasi lingkungan pun tidak bertanggungjawab (Dasgupta, Laplante, Wang, $\&$ Wheeler, 2002).

Beberapa penelitian terdahulu yang menjadi bahan referensi penelitian yaitu:

1. Sudharshan (2017) yang meneliti mengenai "The Effects of Tourism on Economic Growth and CO2 Emissions: A Comparison between Developed and Developing Economies" dimana variabel yang diambil yaitu investasi pariwisata, perkembangan pariwisata ,dan Emisi CO2. Dimana pada penelitian tersebut menjelaskan bahwa kegiatan pariwisata memiliki pengaruh terhadap Emisi CO2. Dalam penelitian tersebut menjelaskan bahwa pertumbuhan ekonomi membirikan pengaruh terhadap Emisi $\mathrm{CO} 2$, jika pertumbuhan ekonomi naik maka Emisi $\mathrm{CO} 2$ juga akan naik hal tersebut terjadi di negara berkembang

2. Sudharshan (2018) yang meneliti mengenai "The effect of tourism investment on tourism development and $\mathrm{CO} 2$ emissions: Empirical evidence from the EU nations" dimana variabel yang diambil yaitu pertumbuhan ekonomi, pariwisata dan Emisi CO2. Dimana pada penelitian tersebut menjelaskan bahwa kegiatan pariwisata memiliki pengaruh terhadap Emisi $\mathrm{CO}$, hal ini karena kegiatan pariwisata juga melibatkan penggunaan transportasi, yang dapat menyumbang polusi udara. 


\section{METODE PENELITIAN}

Jenis dan Sumber Data

Jenis data yang digunakan dalam penelitian ini merupakan data sekunder, yaitu data primer yang sudah diolah dan diperoleh dari pihak lain atau kita tidak mengambil sendiri secara langsung. Data yang kita peroleh bersumber dari World Bank 2018 dan Badan Pusat Statistik (BPS) Indonesia tahun 2018. Jenis data yang digunakan adalah data time series. Data time series periode tahun 1967 - 2015 .

\section{Model Analisis}

Data yang diteliti meliputi pertumbuhan ekonomi, jumlah wisata mancanegara yang datang ke indonesia dan emisi CO2. Jenis penelitiannya merupakan penelitian kuantitatif, dan lokasi penelitian saya mengambil indonesia. Metode analisis data dalam penelitian ini adalah analisis OLS (Ordinary Least Square) dengan pengertian suatu metode ekonometrik dimana terdapat variabel independen yang merupakan variabel penjelas dan variabel dependen yaitu variabel yang dijelaskan dalam suatu persamaan linier. Dalam OLS hanya terdapat satu variabel dependen, sedangkan untuk variabel independen jumlahnya bisa lebih dari satu. Jika variabel bebas yang digunakan hanya satu disebut dengan regresi linier sederhana, sedangkan jika variabel bebas yang digunakan lebih dari satu disebut sebagai regresi linier majemuk atau regresi linier berganda. Sedangkan model ekonometrik atau model yang dapat ditaksir dalam penelitian ini sebagai berikut:

$\mathrm{Y}=\beta 0+\beta 1 \mathrm{X} 1+\beta 2 \mathrm{X} 2+\pi \mathrm{t}$

dimana:

$\mathrm{Y}$ adalah emisi $\mathrm{CO} 2$ pada tahun $\mathrm{t}$,

$\mathrm{X} 1$ adalah pertumbuhan ekonomi di Indonesia pada tahun $\mathrm{t}$,

X2 adalah Pariwisata (jumlah wisman) pada tahun $\mathrm{t}$.

\section{Kerangka Pemikiran}

Kerangka pemikiran merupakan sintesa dari serangkaian teori yang tertuang dalam tinjauan pustaka, yang pada dasarnya merupakan gambaran sistematis dari kinerja teori dalam memberikan solusi atau alternatif solusi dari serangkaian masalah yang ditetapkan (Hamid,
2009-26). Emisi CO2 merupakan salah satu masalah lingkungan yang dihadapi sebuah negara. Salah satu penyebab adanya Emisi CO2 ini disebabkan oleh aktivitas manusia yang menghasilkan polusi dari kendaraan maupun teknologi-teknologi yang kurang ramah lingkungan. Disini juga pertumbuhan ekonomi menjadi salah satu faktor emisi co2 menurut teori yang ada untuk negara yang masih berkembang pertambahan nilai pertumbuhan ekonomi akan diikuti juga bertambahnya nilai Emisi CO2. Selain pertumbuhan ekonomi faktor yang mempengaru bertambahnya nilai Emisi CO2 yaitu pariwisata disini saya mengambil jumlah wisman, menurut teori semakin bertambahnya wisman yang datang akan meningkatkan Emisi CO2 di negara tersebut. maka dapat terbentuk kerangka pemikiran penelitian seperti yang digambarkan pada Gambar 2 berikut ini:

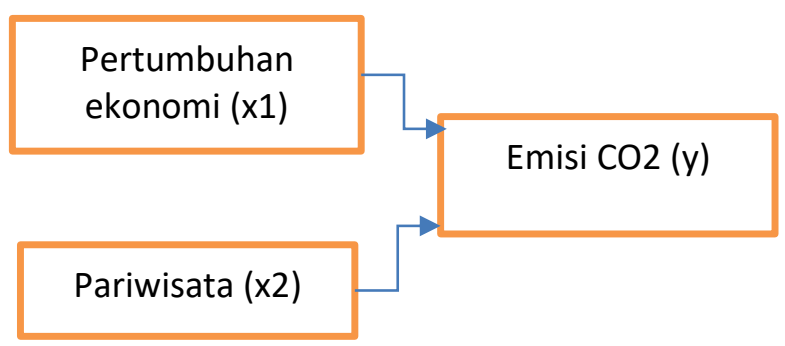

Gambar 2 Kerangka Pemikiran Penelitian

Berdasarkan perumusan masalah yang ada, maka untuk menguji signifikasi masing-masing variabel independen dapat dilakukan dengan uji t dengn membandingkan probabilility value tstatistik dengan nilai alfa yang digunakan yaitu $\alpha$ $=5 \%(0,05)$, bila probability value t-statistik $<\alpha=$ $5 \%(0,05)$ maka Ho ditolak, dan juga sebaliknya.untuk melihat signifikasi dari variabel independen secara keselruhan terhadap variabel dependen independen secara keseluruhan terhadap variabel dependen dapat dilakukan dengan membandingkan probability value Fstatistik $<\alpha=5 \%(0,05)$ maka Ho ditolak, dan juga sebaliknya. Pada penelitian ini diasumsikan bebas dari asumsi klasik serta menggunakan uji hipotesis diantaranya yaitu uji parsial (uji t), uji simultan (uji F), dan koefisien determinasi $\left(\mathrm{R}^{2}\right)$. 


\section{Uji t}

Menurut Ghozali (2012: 98) Uji beda t-test digunakan untuk menguji seberapa jauh pengaruh variable independen yang digunakan dalam penelitian ini secara individual dalam menerangkan variable dependen secara parsial. Dasar pengambilan keputusan yang digunakan dalam uji t adalah sebagai berikut:

1. Jika nilai probabilitas signifikasi $>0.05$, maka hipotesis ditolak.

Hipotesis ditolak memiliki arti bahwa variable independen tidak berpengaruh secara signifikan terhadap variable dependen.

2. Jika nilai probabilitas signifikasi $<0.05$, maka hipotesis diterima.

Hipotesis diterima memiliki arti bahwa variable independen berpengaruh secara signifikan terhadap variable dependen.

Uji F

Menurut Ghozali (2012: 98) Uji statistic F pada dasarnya menunjukan apakah semua variable independen yang dimasukan ke dalam model mempunyai pengaruh secara bersama-sama terhadap variable dependen. Untuk menguji hipotesis ini digunakan statistic $\mathrm{F}$ dengan kriteria pengambilan keputusan sebagai berikut :

1. Jika nilai $\mathrm{F}>4$, maka $\mathrm{H}_{0}$ ditolak pada derajat kepercayaan $5 \%$

2. Membandingkan nilai $F$ hitung dengan $F$ table, jika $\mathrm{F}_{\text {hitung }}>\mathrm{F}_{\text {tabel }}$ maka $\mathrm{H}_{0}$ ditolak dan menerima $\mathrm{Ha}$

\section{Koefisien Determinasi $\left(\mathbf{R}^{2}\right)$}

Menurut Ghozali (2012: 97) koefisien determinasi $\left(\mathrm{R}^{2}\right)$ pada intinya mengukur seberapa jauh kemampuan model dalam menerangkan variasi variable independen. Nilai koefisien determinasi adalah nol dan satu. Nilai $\mathrm{R}^{2}$ yang kecil berarti kemampuan variable independen dalam menjelaskan variabel-variabel dependen amat terbatas. Dalam kenyataan nilai $\mathrm{R}^{2}$ dapat bernilai negative, walaupun yang dikehendaki harus bernilai positif. Jika dalam uji empiris didapat adjusted $\mathrm{R}^{2}$ negatif, maka nilai adjusted $\mathrm{R}^{2}$ dianggap bernilai nol.

Untuk pengujian selengkapnya dapat dirumuskan dengan hipotesis sebagai berikut:
1. Pertumbuhan ekonomi diduga berpengaruh signifikan terhadap Emisi CO2. Kenaikan pertumbuhan ekonomi akan meninkatakan Emisi CO2 di Indonesia.

Ho $\alpha 1$ = Artinya, pertumbuhan ekonomi tidak berpengaruh signifikan terhadap Emisi $\mathrm{CO} 2 \mathrm{di}$ Indonesia.

Ho $\alpha 1 \neq$ Artinya, pertumbuhan ekonomi berpengaruh signifikan terhadap Emisi CO2 di Indonesia.

2. Pariwista (jumlah wisman) diduga berpengaruh signifikan terhadap Emisi CO2. Kenaikan Pariwista (jumlah wisman) akan meninkatakan Emisi $\mathrm{CO} 2$ di Indonesia.

Ho $\alpha 1$ = Artinya, Pariwista (jumlah wisman) tidak berpengaruh signifikan terhadap Emisi $\mathrm{CO} 2$ di Indonesia. Ho $\alpha 1 \neq$ Artinya, Pariwista (jumlah wisman) berpengaruh signifikan terhadap Emisi CO2 di Indonesia.

\section{HASIL DAN PEMBAHASAN}

Setelah diregresikan data yang telah diperoleh maka persamaan regresi berikut dan kemudian akan dianalisis dengan menggunakan hasil regresi berikut ini :

\section{Emisi CO2 $=-9.973435+0.28014$ 6GDP + 0.190763jumlah wisman $+\mu$}

Tabel 1. Hasil Estimasi

\begin{tabular}{|l|r|r|l|}
\hline \multicolumn{1}{|c|}{ Variabel } & Coefficient & \multicolumn{1}{c|}{ t-stat } & Prob. \\
\hline C & -9.973435 & -19.92125 & 0.0000 \\
\hline LOG(GDP) & 0.280146 & 8.648759 & 0.0000 \\
\hline $\begin{array}{l}\text { LOG(JUMLAH_ } \\
\text { WISATAWAN) }\end{array}$ & 0.190763 & 6.714795 & 0.0000 \\
\hline R-squared & \multicolumn{3}{|c|}{0.966536} \\
\hline Prob(F-statistic) & \multicolumn{3}{|c|}{0.000000} \\
\hline
\end{tabular}

Berdasarkan hasil model estimasi dapat diinterpretasikan sebagai berikut :

- Tingkat petumbuhan ekonomi (GDP) (x1) mempunyai pengaruh positif dan signifikan terhadap tingkat emisi $\mathrm{CO} 2$ di indonesia dengan besar 0.280146. Artinya apabila pertumbuhan ekonomi naik sebesar $1 \%$ 
maka tingkat emisi CO2 di indonesia naik sebesar $0.280146 \%$ dengan asumsi citeris paribus.

- Jumlah wisman (X2) mempunyai pengaruh positif dan signifikan terhadap tingakat emisi $\mathrm{CO} 2$ di indonesia dengan besar 0.190763 . Artinya apabila jumlah wisman naik sebesar $1 \%$ maka tingkat emisi CO2 di indonesia akan naik sebesar $0.190763 \%$ dengan asumsi citeris paribus.

\section{Uji t (Uji Parsial)}

Uji $t$ merupakan pengujian secara individual untuk membuktikan bahwa koefisien regresi ini secara statistic signifikan.

$\mathrm{H} 0: \beta 1=0$ (tidak ada pengaruh pertumbuhan ekonomi)

H1 : $\beta 2 \neq 0$ (ada pengaruh pertumbuhan ekonomi)

Kriteria penerimaan atau penolakan sebagai berikut :

Tolak H0 jika nilai probabilitas $\mathrm{t}<$ dari taraf signifikan sebesar $0,05($ sig $<\alpha 0,05)$

Terima $\mathrm{HO}$ jika nilai probabilitas $\mathrm{t}>$ dari taraf signifikan sebesar 0,05 (sig $>\alpha 0,05$ )

Dari hasil pengolahan hasil berikut ini:

- Nilai probabilitas pertumbuhan ekonomi sebesar 0.0000

Nilai t-tabel 1,684, Nilai t-statistik 8.648759

hal ini berarti 0,0008 $<0,05$ atau t-tabel 1,684< t-statistik 3.638980 menandakan signifikan, disini berari bahwa pertumbuhan ekonomi mempengaruhi emisi $\mathrm{CO} 2$.

- Nilai probabilitas pariwisata(wisman) sebesar 0.0000

Nilai t-tabel 1,684, Nilai t-statistik 6.714795

hal ini berarti $0,0000<0,05$ atau t-tabel $1,684<$ t-statistik 6.877472

menandakan signifikan, disini berari bahwa pariwisata(wisman) mempengaruhi emisi $\mathrm{CO} 2$.

Uji F

Pada uji $\mathrm{F}$ ini kita dapat melakukan pengujian dengan membandingkan nilai dari prob ( $F$ statistik) dengan nilai $\alpha(0.05)$. Dari hasil estimate regresi tersebut nilai probabilitas ( $F$ statistik) adalah 0.000000 .

Jadi probabilitas (f statistik $)<\alpha$

$0,000000<0,05$
Artinya variabel x1(pertumbuhan ekonomi) dan variabel $\mathrm{x} 2$ (pariwisata) secara bersama-sama berpengaruh signifikan mempengaruhi variabel $\mathrm{y}($ emisi co2) dengan asumsi citeris paribus.

Uji R2 (Uji Koefisien Determinasi) Dari hasil regresi hubungan tingkat pertumbuhan ekonomi dan jumlah wisman terhadap emisi $\mathrm{CO} 2$ di Indonesia tahun 1974 - 2014 diperoleh R2 sebesar 0.966536 . Artinya sebesar $96,6 \%$ variabel independen yaitu pertumbuhan ekonomi dan jumlah wisman di indonesia dapat menjelaskan terhadap variabel dependen yaitu emisi $\mathrm{CO}$, dan sebesar 3,4\% dapat dijelaskan variabel diluar model dengan asumsi citeris paribus.

\section{SIMPULAN}

Penelitian ini bertujuan untuk menguji secara empiris hubungan pariwisata dan pertumbuhan ekonomi terhadap emisi $\mathrm{CO} 2$ menggunakan menggunakan analisis regresi ols di pada dengan data time seris pada tahun 1974 hingga 2014. Temuan dari penelitian ini adalah untuk memahami keterkaitan antara pertumbuhan ekonomi, emisi $\mathrm{CO} 2$, dan pariwisata di negara indonesia.

- Hubungan antara tingkat petumbuhan ekonomi (GDP) (x1) mempunyai pengaruh positif dan signifikan terhadap tingkat emisi CO2 di indonesia dengan besar 0.280146 . Artinya apabila pertumbuhan ekonomi naik sebesar $1 \%$ maka tingkat emisi $\mathrm{CO} 2$ di indonesia naik sebesar $0.280146 \%$ dengan asumsi citeris paribus.Hal ini menunjukan antara teori dan hasil sama. Pada teori kuznes $\mathrm{u}$ terbalik atau $\mathrm{n}$ dimana negara yang masih tergolong miskin dan berkembang dalam meningkatkan pertumbuhan ekonominya tampa memperhatikan lingkungan, diman penggunaan teknologi dalam menunjang perekonomian negara pun masih menggunakan teknologi yang tidak ramah lingkungan karena pada negara berkembang biasanya menggunakan teknologi-teknologi bekas.

- Hubungan antara emisi CO2 dengan pariwisata (wisman) memiliki hubungan 
positif dan signifikan, yang artinya jika ada kenaikan wisman di indonesia akan menaikan emisi CO2 di indonesia. Jumlah wisman (X2) mempunyai pengaruh positif dan signifikan terhadap tingakat emisi CO2 di indonesia dengan besar 0.190763 . Artinya apabila jumlah wisman naik sebesar $1 \%$ maka tingkat emisi $\mathrm{CO} 2$ di indonesia akan naik sebesar $0.190763 \%$ dengan asumsi citeris paribus. Hal ini juga sesuai dengan teori yang ada dimana semakin banyaknyanya wisman yang datang ke Indonesia akan memberikan dampak terhadap lingkungn.

\section{SARAN}

- Untuk kedepannya diharapkan pemerintah indonesia dalam meningkatkan pertumbuhan ekonomi juga memperhatikan keadaan lingkungan juga, apakan kebijakan tersebut dapat menimbulkan efek eksternalitas negatif terhadap lingkungan atau tidak. Sebaiknya juga dalam meningkatkan perekonomian indonesia lebih menekankan penggunaan teknologi yang ramah lingkungan.

- Untuk mengembangkan kebijakan pariwisata berkelanjutan di daerah-daera indonesia yang potensial memunculkan pariwisata - pariwisata. Sebaiknya para wisman kedepanya lebih disarankan untuk menggunakan transportasi umum, sehingga dapat mengurangi pengoprasian kendaraan di indonesia. Dan unuk mendukung hal tersebut saran yang saya berikan agar kedepanya pemerintah mau menyediakan transportasi umum yang layak dan lebih ramah lingkungan.

\section{DAFTAR PUSTAKA}

Alam, M.S., \& Paramati, S.R. (2015). Do oil consumption and economic growth intensify environmental degradation? Evidence from developing economies. Applied Economics, 47, 5186-5203.

Alam, M. S., Paramati, S. R., Shahbaz, M., \& Bhattacharya, M. (2016). Natural gas, trade and sustainable growth: empirical evidence from the top gas consumers of the developing world. Applied Economics, 1-15.

Cárdenas-García, P.J., Sánchez-Rivero, M., \& Pulido-Fernández, J.I. (2015). Does tourism growth influence economic development? Journal of Travel Research, 54(2), 206-221.

Durbarry, R., \& Seetanah, B. (2015). The impact of long haul destinations on carbon emissions: The case of mauritius. Journal of Hospitality Marketing \& Management, 24(4), 401-410.

León, Carmelo J, Arana, Jorge E, \& Hernández, Anastasia. (2014). $\quad \mathrm{CO}_{2}$ emissions and tourism in developed and less developed countries. Applied Economics Letters, 21(16), 1169-1173.

Tang, Zi, Shang, Jie, Shi, Changbo, Liu, Zheng, \& Bi, Kexin. (2014). Decoupling indicators of CO 2 emissions from the tourism industry in China: 1990-2012. Ecological Indicators, 46, 390-397.

Ridderstaat, Jorge, Croes, Robertico, \& Nijkamp, Peter. (2016). The Tourism DevelopmentQuality of Life Nexus in a Small Island Destination. Journal of Travel Research, 55 (1), 79-94.

Saidi, Kais, \& Hammami, Sami. (2015). Economic growth, energy consumption and carbon dioxide emissions: recent evidence from panel data analysis for 58 countries. Quality \& Quantity, 1-23.

Tsai, K.-T., Lin, T.-P., Hwang, R.-L., \& Huang, Y.-J. (2014). Carbon dioxide emissions generated by energy consumption of hotels and homestay facilities in taiwan. Tourism Management, 42, 13-21.

Zaman, K., Shahbaz, M., Loganathan, N., \& Raza, S. A. (2016). Tourism development, energy consumption and Environmental Kuznets Curve: Trivariate analysis in the panel of developed and developing countries. Tourism Management, 54, 275-283.

Alam dan Paramati (2015). The effects of tourism on economic growth and $\mathrm{CO}_{2}$ emissions: Acomparison between developed and developing economies. According to the International Statistical Institute

Başarir, Çağatay , Yasin Nuri Çakir. 2015. Causal Interactions Between Co2 Emissions, Financial Development, Energy And Tourism. Asian Economic and Financial Review, 2015, 5(11):1227-1238.

Ng, T.H., Lye, C.T. \& Lim, Y.S. (2015). A decomposition analysis of co2 emissions: Evidence from malaysia's tourism industry. 
International Journal of Sustainable Development \& World Ecology, 1-12.

Paramati, S.R., Alam, M.S., \& Chen, C.F. (2016). The Effects of Tourism on Economic Growth and $\mathrm{CO} 2$ Emissions A Comparison between Developed and Developing Economies. Journal of Travel Research, 0047287516667848

Galeotti, M. (2007). Economics Growth and The Quality of The Environment: Taking Stock. Environment, Development, and Sustainability.

Phillips, J., Faulkner, J. and International, S. (2015). Tourism investment and finance accessing sustainable funding and social impact capital. United States Agency for International Development

Paramati S .R., Samsul A., Chi K .M .L . (2017). The Effects of Tourism on Economic Growth and CO2 Emissions: A Comparison between Developed and Developing Economies. Journal of Travel Research. Vol. 56(6) 712-724.

Balaguer, Jacint, \& Cantavella-Jorda, Manuel. (2002). Tourism as a long-run economic growth factor: the Spanish case. Applied economics, 34(7), 877-884.

Kuznet, S. (1955). Economic growth and income inequality. The American Economic

Review, XLV (1). 1-28.

Becken, Susanne, \& Simmons, David G. (2002). Understanding energy consumption patterns of tourist attractions and activities in New Zealand. Tourism Management, 23(4), 343354.

Paramati S .R., Samsul A., Chi K.M .L . (2018). The effect of tourism investment on tourism development and $\mathrm{CO} 2$ emissions: Empirical evidence from the EU nations. Journal of Sustainable Tourism.

Nikensari, S. I., Destilawati, S., \& Nurjanah, S. (2019). Studi Environmental Kuznets Curve Di Asia: Sebelum Dan Setelah Millennium Development Goals. Jurnal Ekonomi Dan Pembangunan Vol 27, No. 2, 11-25.

Nizar, M. A. (2015). Pengaruh Pariwisata Terhadap Pertumbuhan Ekonomi Di Indonesia. MPRA Paper No. 65628. 